\title{
皮電計による輸血後肝炎防除に関する研究
}

$$
\begin{aligned}
& \text { 千城園 後 藤 繁 小池栄 治 } \\
& \text { 長浜療盖所田中益雄駒井士 朗 } \\
& \text { 緑ヶ丘保養所関本信田代安司 } \\
& \text { 天竜荘真島武野口口佁 } \\
& \text { 梅森光風園 鶴 田晃夫 } \\
& \text { 大府荘 横内寿八郎栗田一 郎 } \\
& \text { 兵庫療湌所 田 村 政 司 } \\
& \text { 加古川療養所 辻川 春 季 } \\
& \text { 神戸療湌所 新田 俊 男 } \\
& \text { 。島根療養所 藤 野 道夫 鈴 木 典子 } \\
& \text { 日本ブラッドバンク内 藤 良一北野政次 } \\
& \text { 大田黒 猪一郎生垣賢 } \\
& \text { 谷川十三生 }
\end{aligned}
$$

\section{STUDIES ON THE PREVENTION OF POSTTRANSFUSION} HEPATITIS BY THE ELECTRODERMATOGRAPHY

\author{
by \\ Shigeru Goto, Eiji KoIKe (Senjo-en), \\ Masuo TANAKa, Shiro Komai (Nagahama Sanatorium) \\ Shin Sekimoto, Yasuji TAshiro (Midorigaoka Sanatorium) \\ Takeshi MajIma, Makoto Noguchi (Tenryuso) \\ Akio TSURUTA (Bairin-Kofu-en) \\ Juhachiro Yokouchi, Ichiro KuRIta (Daifuso) \\ Masashi TAMURA (Hyogo Sanatorium) \\ Haruki TSUJIKAwA (Kakogawa Sanatorium) \\ Toshio NitTa (Kobe Sanatorium) \\ Ryoichi NaIto, Masaji Kitano, Iichiro Otaguro, \\ Ken Ikegaki \& Tomio Tanigawa \\ (Blood Plasma Corporation of Japan)
}

\begin{abstract}
After two and half years experiments we have reached the conclusion that the electrodermatography is an effective screening of donors to prevent the posttransfusion hepatitis.
\end{abstract}

流行性肝炎の発生頻度は, 世界各国に於て, 増 加の傾向を示し, 輸血後旰炎も亦增加しつ>ある 現況である.日本に於ては輸血後旰炎急増の現況 と, その重要性に鑑み1963年国際旰葴研究会日本 
支部総会に於て, 血清旰炎の実態と, その予防対 策について, シンポジウムが行われ，又日本輸血 学会に於ても, 血清旰於調査委員会を設けて,引 続きその実態を調查し，今後の対策を検討中であ る。

従来肝炎ウイルス保有者たる䂑のある供血者を 排除する企図を以て, 幾多の䀒機能検査が試みら れた。例えば血清ビリルビン, 黄疸指数, チモー ル溷浊試験, セフアリン沈降区応, SGOT, S GP T等である.

石川教授は創案した皮電計によつて，䀒機能障 害が血清や尿を対象とする生化学的手段と異つた 機序によつて検査できることを発見し，内藤等は 1960年第 8 回国際輸血学会に於て, この石川式 皮電計を使用しての輸血後肝炎のスクリーニング の成績を発表し，その後更に実験方法を検討し， 1963年第 1 回アジア輸血会議に於て, 中間報告を なした。

今やその実験例数も500以上に到達したので， こ>に之を取纒め報告する次第である.

\section{実験方法}

1. 1962年 2 月より日本ブラッド・バンク東京 プラントに於て, 凡ての供血者に対し, 䀒臓部の 石川式皮電計検查を行い, 検査部位に於て 2 力以 上の皮電点を認め，そのうち少くとも 1 ケ以上が 70以上のメーター指針を示したものを「皮電計陽 性と制定し，その成績を記録する。

2. 皮電計検查成績の如何に拘らず，任意に保 存血液を供給する.

3. 実験療屋所は胸部（肺）の手術が多く行わ れ, 被手術者が術後概ね 6 力月以上の期間入院を 続け, 䀒炎発症の観察が可能である.

4. 療養所に於ける観察と記録は最初の輸血の
日から40日と, 最後の輸血の日から 160 日の間を 観察し, 次の 5 種類の肝機能検查を概ね 1 週間 1 回行う。1)皮膚又は渾膜の黄染, 2)尿ビリル ビン，3）尿ウロビリノーゲン，4） TTT, 5) $\mathrm{SGOT}$.

5.この実験の客観性を求めるために, 療湌所 側では，使用する血液の「皮電計陽性又は陰性」 を全く知らされないで, アトランダムに輸血を行 い,その後の発症を観察したのち対比する.

6. 実験療養所を增して, 観察例数を 500 以上 に達せしめるため, 1963年 5 月より京都, 神戸， 名古屋の各支店管内の療養所 7 力所も, 共同研究 に参加し, 10ケの療養所で実験を行つた。

\section{実験成績}

1. 皮電計による検查成績

1962年 2 月20日より，1964年 4 月30日迄の約 2 力年間の検査人員は，44万9764名で，その内皮電 計陽性者は 3 万6019名，その陽性率は $8.0 \%$ あ る.

\section{2. 各療養所に於ける観察例数}

表 1 に示すが如く, 長演療養所の 155 例最も多 く, 島根の 99 例これにつぎ, 最も少きは大府荘の 9 例で, 計 530 例である.

その内訳は皮電計陽性血の入つた群は210例 で, 皮電計陽性血の入ら群は 320 例である.こ >に皮電計陰性血の言葉を使わなかつたのは, 皮 電計疑陽性は陽性群に含まず，皮電計陽性血の入 らぬ群に含まれているからである。

3. 輸血量の調查成績

表 2 に示すが如く，皮電計陽性血の入つた群 は 210 例で, 受血者の 1 人平均輸血量は $2116 \mathrm{~m}^{1}$ （最大 $9400 \mathrm{ml}$, 最少 $400 \mathrm{ml}$ ), 皮電計陽性血の入 らぬ群は, 320 例で, 1 人平均輸血量は $1522 \mathrm{ml}$

表 1 療養所別実験数

\begin{tabular}{|c|c|c|c|c|c|c|c|c|c|c|c|}
\hline 療 養 所 & 長演 & 緑ヶ丘 & 千城園 & 天竜草 & 梅森光 & 大府荘 & 島根 & 神戸 & 兵庫 & 加古川 & 計 \\
\hline 輸血の区分 & 155 & 86 & 81 & 12 & 15 & 9 & 99 & 10 & 24 & 24 & 530 \\
\hline $\begin{array}{l}\text { 皮電計陽性血 } \\
\text { の入つた群 }\end{array}$ & 62 & 29 & 34 & 5 & 4 & 3 & 49 & 3 & 6 & 6 & 210 \\
\hline $\begin{array}{l}\text { 皮電計陽性血 } \\
\text { の大ら群 }\end{array}$ & 93 & 57 & 47 & 7 & 11 & 6 & 50 & 7 & 18 & 18 & 320 \\
\hline
\end{tabular}


（最大 $8200 \mathrm{ml}$ ，最小 $200 \mathrm{ml}$ ）で皮電計陽性血の 入つた群の方が平均約 $600 \mathrm{ml}$ 多い.

\section{4. 各療養所の所見集計}

輸血後盰炎の診断にあたつては, 畈機能検査の みに依存することなく，一般臨床症状と経過の注 意深い観察を重視すべきことは勿論であるが，未 だ適切な䀒炎の断診基準なきため, 今回の調査に
表 2 輸血量の調查成績

\begin{tabular}{|c|c|c|c|c|}
\hline & & \multicolumn{3}{|c|}{ 輸血量 $\mathrm{ml}$} \\
\hline 輸血 & 又亚白阵 & 平 均 & 最 大 & 最 少 \\
\hline $\begin{array}{l}\text { 皮電計陽性血| } \\
\text { の入つた群 }\end{array}$ & 210 & 2116 & 9400 & 400 \\
\hline $\begin{array}{l}\text { 皮電計陽性血 } \\
\text { の入らぬ群 }\end{array}$ & 320 & 1522 & 8200 & 200 \\
\hline
\end{tabular}

表 310 療養所の所見集計

\begin{tabular}{|c|c|c|c|c|c|c|c|c|c|c|}
\hline \multirow[t]{2}{*}{ 検 査 } & \multirow[b]{2}{*}{ 患者数 } & \multirow[b]{2}{*}{ 黄 疸 } & \multirow{2}{*}{$\begin{array}{l}\text { ビリル } \\
\text { ビン尿 }\end{array}$} & \multirow{2}{*}{$\begin{array}{l}\text { ウロビ } \\
\text { リノー } \\
\text { ゲン尿 }\end{array}$} & \multicolumn{3}{|c|}{ T T T } & \multicolumn{3}{|c|}{ SGOT } \\
\hline & & & & & 4 以下 & $\begin{array}{r}4.1- \\
5.9\end{array}$ & 6 以上 & 40 以下 & $41-99$ & 100 以上 \\
\hline $\begin{array}{l}\text { 皮電計陽性血 } \\
\text { の入つた群 }\end{array}$ & 210 & $\begin{array}{c}31 \\
(14.8) \\
\end{array}$ & $\begin{array}{c}29 \\
(13.8) \\
\end{array}$ & $\begin{array}{c}112 \\
(53.3) \\
\end{array}$ & $\begin{array}{c}116 \\
(55.2) \\
\end{array}$ & $\begin{array}{c}22 \\
(10.5) \\
\end{array}$ & $\begin{array}{c}72 \\
(34.3) \\
\end{array}$ & $\begin{array}{c}36 \\
(17.1) \\
\end{array}$ & $\begin{array}{r}43 \\
(20.5) \\
\end{array}$ & $\begin{array}{c}131 \\
(62.4)\end{array}$ \\
\hline $\begin{array}{l}\text { 皮電計陽性血 } \\
\text { の入らぬ群 }\end{array}$ & 320 & $\begin{array}{c}18 \\
(5.6)\end{array}$ & $\begin{array}{c}20 \\
(6.3)\end{array}$ & $\begin{array}{c}167 \\
(52.2)\end{array}$ & $\begin{array}{c}181 \\
(56.6)\end{array}$ & $\begin{array}{c}50 \\
(15.6)\end{array}$ & $\begin{array}{c}89 \\
(27.8) \\
\end{array}$ & $\begin{array}{c}90 \\
(28.2) \\
\end{array}$ & $\begin{array}{c}91 \\
(28.4)\end{array}$ & $\begin{array}{c}139 \\
(43.4)\end{array}$ \\
\hline
\end{tabular}

備考（）内\%を示す

於ては, 表 3 に示す 5 種類の畈機能検 査法によ る所見の集計で，黄疸尿ビリルビン，尿ウロビリ ノーゲンの成績は, 観察中 1 回でも陽性に出たも のは，之を陽性とし，チモール溷濁試験について は, MacLagan 単位 4 以下, 4.1-5.9, 6 以 上の 3 つに区分して観察し, 経過中の最高值を集 計した. SGOTについては, 正常限界に問題は あるが, Reitman-Frankel 法で，40単位以下， 41-99，100以上の 3 つに区分して観察し, チモー ル溷浊試験と同様, 経過中の最高值を計討した.

その成續は表 3 に示すが如くである.

黄㾝について観察すれば, 皮電計の陽性血の入 つた群では陽性 31 例, 師ち $14.8 \%$ 発生し, 皮電計 陽性血の入らぬ群では, 陽性18例, 師ち $5.6 \%$ で ある。

尿ビリルビンについては, 皮電計陽性側では, 陽性29例, 師ち 13.8\%で, 対照側では陽性20例, 師ち $6.3 \%$ あ゙る.

尿ウロビリノーゲンについては, 皮電計陽性側 の陽性 112例, 師ち53.3\%で, 対照側の陽性 167 例，師亏 $52.2 \%$ あるる。

チモール溷濁試験については, 皮電計陽性側の 6 以上のものを観察すれば, 72 例, 師ち $34.3 \% に$ 対し，対照側では89例，師ち $27.8 \%$ ある。
S GOTについては，100単位以上を観察すれ ば, 皮電計陽性側の陽性 131例, 師ち62.4\%に対 し, 対照側の陽性 139例, 師ち43.4\%である。

$$
\text { むすび }
$$

約 2 力年半にわたる上記 530 例の実験成績の結 果, 石川式皮電計による皮電点の検索によつて， 供血者のスクリーニングを行うことは，輸血後黄 疸の減少のため, 有効と認めた。

\section{文献}

1）石川大刀雄 : 内臟体壁反射, 医学書院, 1962.

2) Naito, R. \& Morisue, S.: Screening of transfusion hepatitis by means of electrodermatography. Pros. 8th Congr. Int. Soc. Blood Transf., Tokyo 1960, pp. 510-513, 1962.

3) 石川城, 覚野, 渡辺, 砂原, 村山, 中沢, 内 藤他：宠電計を以てする供血者血清畈炎除外 の試み (予報), 日本輸血学会雑誌, $6(6)$ : 340-341. 1960.

4) Goto, S. Tanaka, M. Sekimoto, M. Naito, R. and Kitano, M.: Reduced incidence of hepatitis in blood-recipients by means of donor-screening by electrodermatography. The First Asian Congress of Blood Transfusion, August 1963, pp. 68-69.

5) 後藤, 田中, 関本, 内藤, 北野他: 皮電計に 上る輸血後肝炎防除汇関する研究, 日本輸血学 会雑誌 $9(4,5)$ ：129-131. 1963. 同誌10 (2) : 1963. 57-58 : 同誌10 $(3,4,5)$ : 6465. 1964 . 